\title{
An assessment of two automated snow water equivalent instruments during the WMO Solid Precipitation Intercomparison Experiment
}

\author{
Craig D. Smith ${ }^{1}$, Anna Kontu ${ }^{2}$, Richard Laffin ${ }^{3}$, and John W. Pomeroy ${ }^{4}$ \\ ${ }^{1}$ Environment and Climate Change Canada, Saskatoon, S7N 3H5, Canada \\ ${ }^{2}$ Finnish Meteorological Institute, Sodankylä, 99600, Finland \\ ${ }^{3}$ Campbell Scientific, Edmonton, T5L 4X4, Canada \\ ${ }^{4}$ Centre for Hydrology, University of Saskatchewan, Saskatoon, S7N 5C8, Canada \\ Correspondence to: Craig D. Smith (craig.smith2@canada.ca)
}

Received: 1 March 2016 - Published in The Cryosphere Discuss.: 24 March 2016

Revised: 22 November 2016 - Accepted: 25 November 2016 - Published: 16 January 2017

\begin{abstract}
During the World Meteorological Organization (WMO) Solid Precipitation Intercomparison Experiment (SPICE), automated measurements of snow water equivalent (SWE) were made at the Sodankylä (Finland), Weissfluhjoch (Switzerland) and Caribou Creek (Canada) SPICE sites during the northern hemispheric winters of 2013/14 and 2014/15. Supplementary intercomparison measurements were made at Fortress Mountain (Kananaskis, Canada) during the 2013/14 winter. The objectives of this analysis are to compare automated SWE measurements with a reference, comment on their performance and, where possible, to make recommendations on how to best use the instruments and interpret their measurements. Sodankylä, Caribou Creek and Fortress Mountain hosted a Campbell Scientific CS725 passive gamma radiation SWE sensor. Sodankylä and Weissfluhjoch hosted a Sommer Messtechnik SSG1000 snow scale. The CS725 operating principle is based on measuring the attenuation of soil emitted gamma radiation by the snowpack and relating the attenuation to SWE. The SSG1000 measures the mass of the overlying snowpack directly by using a weighing platform and load cell. Manual SWE measurements were obtained at the intercomparison sites on a bi-weekly basis over the accumulation-ablation periods using bulk density samplers. These manual measurements are considered to be the reference for the intercomparison. Results from Sodankylä and Caribou Creek showed that the CS725 generally overestimates SWE as compared to manual measurements by roughly $30-35 \%$ with correlations $\left(r^{2}\right)$ as high as 0.99 for Sodankylä and 0.90 for Caribou Creek. The RMSE varied from 30 to $43 \mathrm{~mm}$ water equiv-
\end{abstract}

alent (mmw.e.) and from 18 to $25 \mathrm{~mm}$ w.e. at Sodankylä and Caribou Creek, which had respective SWE maximums of approximately 200 and $120 \mathrm{~mm}$ w.e. The correlation at Fortress Mountain was 0.94 (RMSE of $48 \mathrm{~mm}$ w.e. with a maximum SWE of approximately $650 \mathrm{~mm}$ w.e.) with no systematic overestimation. The SSG1000 snow scale, having a different measurement principle, agreed quite closely with the manual measurements at Sodankylä and Weissfluhjoch throughout the periods when data were available $\left(r^{2}\right.$ as high as 0.99 and RMSE from 8 to $24 \mathrm{~mm}$ w.e. at Sodankylä and from 56 to $59 \mathrm{~mm}$ w.e. at Weissfluhjoch, where maximum SWE was approximately $850 \mathrm{~mm}$ w.e.). When the SSG1000 was compared to the CS725 at Sodankylä, the agreement was linear until the start of ablation when the positive bias in the CS725 increases substantially relative to the SSG1000. Since both Caribou Creek and Sodankylä have sandy soil, water from the snowpack readily infiltrates into the soil during melt, even if the soil is frozen. However, the CS725 does not differentiate this water from the unmelted snow. This issue can be identified, at least during the late spring ablation period, with soil moisture and temperature observations like those measured at Caribou Creek. With a less permeable soil and surface runoff, the increase in the instrument bias during ablation is not as significant, as shown by the Fortress Mountain intercomparison. 


\section{Introduction}

The measurement of snow water equivalent (SWE) is vital for flood and water resource forecasting, drought monitoring, climate trend analysis, and hydrological and climate model initialization (Barnett et al., 2005; Bartlett et al., 2006; Gray et al., 2001; Laukkanen, 2004). Many of these applications require accurate and timely information about how much water is being held within the snowpack (Pomeroy and Gray, 1995). SWE measurements can be made in situ, either manually or via automated instrumentation, or derived from remote sensing platforms, and they are usually expressed as units of mass per area $\left(\mathrm{kg} \mathrm{m}^{-2}\right)$ or in equivalent units of millimetres of water equivalent (mm w.e.). Manual measurements of SWE are typically made using a multi-point bulk density sampling technique along an established transect or snow course (WMO, 2008). Snow course measurements are often time consuming and expensive, especially if required in remote locations (Pomeroy and Gray, 1995). This means that manual SWE measurements may be infrequent or only undertaken when the snowpack is estimated to be at its seasonal maximum. Prohibitive costs of manual snow course observations have led to the reduction of these measurements by many agencies, including Environment and Climate Change Canada, where operational snow course numbers have decreased from over 100 in the 1980s to less than 30 (Barry, 1995; Brown et al., 2000). Since the early 1990s, manual SWE measurements have been augmented or replaced by remote sensing techniques such as passive microwave retrievals (Goodison and Walker, 1995) but these techniques still require accurate and reliable in situ measurements for ground truthing and retrieval development (Derksen et al., 2005; Takala et al., 2011).

With the reduced availability of manual SWE measurements, automated instruments for the measurement of SWE are becoming more necessary and more commonplace. Snow pillows have been used for the automated measurement of SWE in remote locations since the 1960s (Beaumont, 1965) by measuring the overlying pressure of the snowpack on a fluid-filled bladder. The SNOTEL network in the United States is based on snow pillow measurements (Serreze et al., 1999). More recently, similar measurements are obtained using snow scales that use a weighing surface and load cell to measure the weight of the overlying snow (Beaumont, 1966a; Johnson et al., 2007, 2015). Several indirect methods exist to measure SWE that include the use of neutron probes (Harding, 1986) in which a radiation source is placed under the snowpack and the scattering of neutrons through the snow is measured by a detector. Cosmic ray proton probes (Kodama et al., 1979; Rasmussen et al., 2012) work in a similar manner but do not require an active source. The probes described by Kodama et al. (1979) are installed under the snow while the system described by Rasmussen et al. (2012) (called COSMOS) is installed above the snow. Kinar and Pomeroy (2007, 2015a) outline a method of non-invasive sonic reflectome- try through the snowpack to determine snow density, liquid water content and temperature. Other passive radiation sensors are mounted above the surface and measure the attenuation of naturally emitted radiation from the soil as it passes through the snowpack and then relate this attenuation to SWE content (Choquette et al., 2008; Martin et al., 2008). Each of these instruments and techniques have advantages and disadvantages, which are not discussed here (see Kinar and Pomeroy, 2015b, for a more comprehensive description of snow measurement methods and related issues). Rather, this analysis assesses the use and accuracy of two instruments that were tested during the World Meteorological Organization (WMO Solid Precipitation Intercomparison Experiment (SPICE) (Nitu et al., 2012; Rasmussen et al., 2012), namely the Campbell Scientific CS725 and the Sommer Messtechnik SSG1000 snow scale.

The CS725 (previously known as GMON or GMON3) has been previously field tested by Hydro Québec (Choquette et al., 2008; Martin et al., 2008) as well as by Wright et al. (2011). Results by Choquette et al. (2008) showed an average error of $+18 \%$ when comparing to eight manual snow cores over three seasons in Québec. They obtained a somewhat better agreement with total SWE calculated from density profiles (with an average error of $+5 \%$ ) but only had four samples over two seasons. Wright et al. (2011) showed intercomparison results between GMON3 sensors and snow pillows, precipitation gauges and snow courses at Sunshine Village (Alberta, Canada) and Tony Grove Ranger Station (Utah, USA). Results showed high correlations between the sensor and (unadjusted) accumulated precipitation $(0.99)$ and between the sensor and snow pillow observations (0.99) but lower correlations (0.83) with snow course observations (during one season at Sunshine Village). The authors question the quality and inherent biases in the snow course samples but do not comment on the sources of error or the proximity of the snow course to the instrument.

Instrument intercomparisons that included the SSG1000 have been limited but some results are reported by Stranden and Grønsten (2011), who showed parallel SWE measurements between snow pillows, snow scales and manual snow courses. With mitigating circumstances (e.g. snow drifting and scale issues), they concluded that the measurement surface area had an impact on the measurement quality and that the Sommer scale gave "promising results" but that further intercomparison was required.

One of the overall objectives of the WMO-SPICE project is to assess the performance of automated instrumentation for the measurement of snow, including snow on the ground (SoG). This is accomplished by comparing the tested instruments to an established reference measurement. In total, 15 countries are participating in the WMO-SPICE project with about 20 intercomparison sites. Of these, seven countries and nine intercomparison sites are hosting SoG instrumentation. The instrumentation for WMO-SPICE has either been provided by the instrument manufacturers or by the site hosts. 
For SoG, 13 different instruments are under test with 9 measuring snow depth and 4 measuring SWE. The CS725 and the SSG1000 SWE instruments examined here were installed at the Sodankylä (Finland), Caribou Creek (Canada) and Weissfluhjoch (Switzerland) intercomparison sites (Fig. 1). To supplement the CS725 data collected for WMO-SPICE, data were added from an additional CS725 instrument installed at the Fortress Mountain ski area in the Kananaskis region of the Canadian Rocky Mountains.

\section{Instrumentation and methods}

\subsection{Campbell Scientific CS725}

The CS725 (Fig. 2, left) is a passive gamma sensor developed by Hydro Québec in collaboration with Campbell Scientific (Canada) Corp. (Choquette et al., 2008; Martin et al., 2008). The instrument is installed above the snow surface and determines SWE by measuring naturally emitted gamma radiation from potassium (K) and thallium (Tl) sources in the soil that is attenuated by the snowpack. Each gamma ray detected by the sensor element is counted over a user defined period, the resulting distribution is compared to the distribution when there was no snow cover, and the difference is used to calculate SWE. The sensor field of view is approximately $120^{\circ}$, resulting in a measurement area of approximately $80 \mathrm{~m}^{2}$ when installed $3 \mathrm{~m}$ above the snowpack and with the collimator attached. The collimator serves to shield the instrument from gamma rays emitted from sources that are not in the target area. The effective range of the instrument is $0-600 \mathrm{~mm}$ w.e. with a measurement accuracy of $\pm 15 \mathrm{~mm}$ w.e. from 0 to $300 \mathrm{~mm}$ w.e. and $15 \%$ from 300 to $600 \mathrm{~mm}$ w.e. (Campbell Scientific CS725 manual, https://s. campbellsci.com/documents/ca/manuals/cs725_man.pdf).

The two CS725 instruments for WMO-SPICE were both installed in October 2013 at Sodankylä, Finland, and Caribou Creek, Canada, and operated over the northern hemispheric winters of 2013/14 and 2014/15. Both instruments were mounted so that the bottom of the instrument was approximately $2 \mathrm{~m}$ above the ground and both were installed with the manufacturer provided collimator. Data were output every $6 \mathrm{~h}$. The instrument at Sodankylä was moved approximately $10 \mathrm{~m}$ during the summer of 2014 to avoid some buried cables in the measurement area, but any potential impact of the move is considered to be negligible because of the consistency in the snowpack at this site. The impact of spatial variability is addressed in Sect. 4.

The third CS725 used in this analysis was not a WMOSPICE instrument, but it was loaned to the University of Saskatchewan for testing and intercomparison by the instrument manufacturer. This instrument was installed in a clearing near the Fortress Mountain ski resort in the Kananaskis Valley, Alberta, Canada. The CS725 was mounted at a height of approximately $3.5 \mathrm{~m}$ above the ground. The distance to the

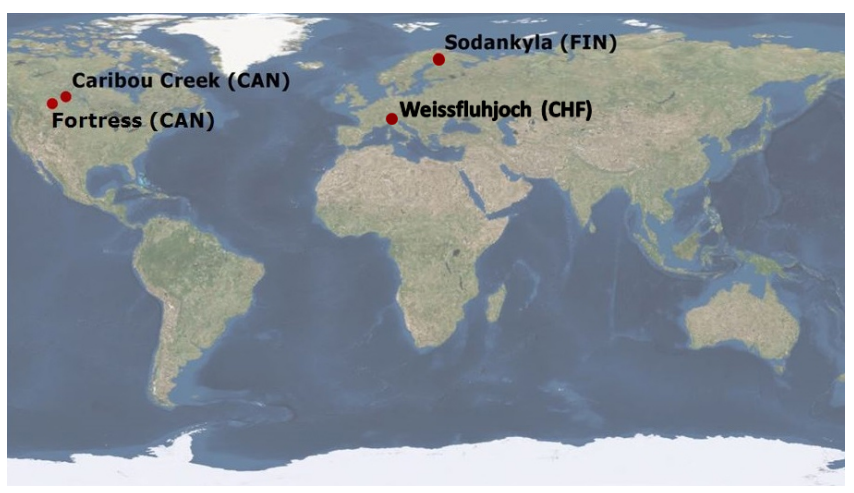

Figure 1. Location of the CS725 (Sodankylä, Caribou Creek, Fortress Mountain) and SSG1000 (Sodankylä and Weissfluhjoch) instrument intercomparisons.

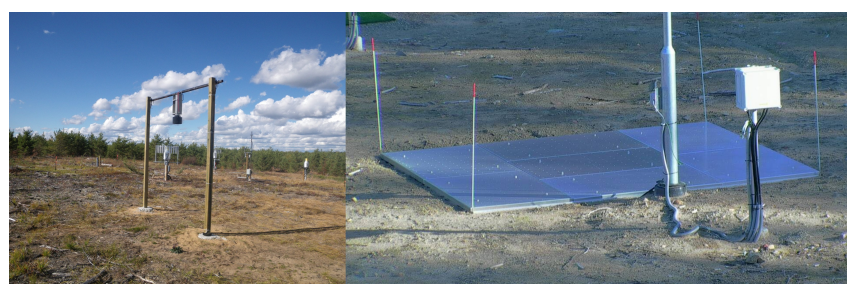

Figure 2. The Campbell Scientific CS725 (left) installed at Caribou Creek and the Sommer Messtechnik SSG1000 (right) installed at Sodankylä.

trees around the instrument was approximately $10 \mathrm{~m}$ from the centre of the instrument, putting them outside of the response area. Data collected by this instrument from October 2013 through June 2014 are used in this analysis. Like the other CS725 instruments, SWE data were output every $6 \mathrm{~h}$.

\subsection{Sommer SSG1000}

The SSG1000 snow scale (Fig. 2, right) manufactured by Sommer Messtechnik, Austria, measures SWE through the use of a weighing platform and load cells. Unlike the CS725, it makes a direct measurement of the weight of the snowpack on top of the weighing platform and converts this weight to SWE. The entire platform consists of seven perforated panels, each $0.8 \mathrm{~m} \times 1.2 \mathrm{~m}$, that are attached to a frame and installed level with the surface of the ground. The entire instrument surface is $2.8 \mathrm{~m} \times 2.4 \mathrm{~m}\left(6.72 \mathrm{~m}^{2}\right)$ but only the centre panel is weighed by the load cell. According to the manufacturer, the purpose of the larger surface surrounding the centre measurement panel is to "stabilize" the overlying snowpack and prevent ice bridging (http://www.sommer. at/en/products/snow-ice/snow-scales-ssg). The SSG1000, as tested for WMO-SPICE, has a measurement range of 0 to $1000 \mathrm{~mm}$ w.e., and a manufacturer-stated resolution and accuracy of $0.1 \mathrm{~mm}$ w.e. and $0.3 \%$ of full scale ( $3 \mathrm{~mm}$ w.e.), respectively. 
The SSG1000 snow scales in this analysis were installed in the Sodankylä and Weissfluhjoch SPICE sites. The Weissfluhjoch instrument was provided by the WSL Institute for Snow and Avalanche Research SLF. Data collection from the instrument started in October 2013 and continued for the 2013/14 and 2014/15 northern hemispheric winters. The SSG1000 at Sodankylä was located in the northeast quadrant of the SPICE Field, approximately $22 \mathrm{~m}$ southeast of the original location of the CS725. At Weissfluhjoch, it is located in the southwest corner of the instrument field. SWE observations from the instruments were recorded once per minute during the two intercomparison seasons.

\subsection{Reference SWE measurements}

The reference SWE manual measurements for this intercomparison differed by site. All were bulk density snow samples made with a snow sampling tube of a known diameter that has one end capable of penetrating and cutting into the snowpack. The tube was inserted into the snowpack either down to the surface of the ground or to a plate inserted into the snowpack, and the sample was extracted. Along with the sample, the depth of the snowpack was also obtained. The sampled snow was then either bagged and weighed or was weighed inside the tube using a cradle and balance. The snow sampler used in Canada is different than the tube used in Finland and these differences, as well as any other differences in sampling technique, are described below.

At Caribou Creek, the reference SWE measurements were obtained using an ESC-30 snow tube with a $30 \mathrm{~cm}^{2}$ cutting area. Farnes et al. (1983) and Goodison et al. (1987) show that the ESC-30, when used correctly and in ideal conditions, has a mean measurement error of less than $0.5 \%$ of the true SWE. Errors associated with sampling in less than ideal conditions are discussed later. Bulk density samples at Caribou Creek were taken just inside the response area of the CS725, bagged and weighed. A $30 \mathrm{~cm}^{2}$ sample from within the response area is assumed to have a negligible impact on future sensor measurements considering the total sensor response area is $80 \mathrm{~m}^{2}$, but it was filled in with discarded snow when possible. These manual SWE measurements were made about every 2 weeks in conjunction with a full five-point snow course across the intercomparison field and into the forest canopy on each side.

At Sodankylä, the reference SWE measurement was made using a Finnish bulk density sampling tube, with a sampling area of $78.54 \mathrm{~cm}^{2}$, and balance (Kuusisto, 1984) at roughly the same location in the intercomparison field every 2 weeks. Only one sample was measured at a time. During the winter of 2013/14, the bulk density SWE sample was obtained approximately $12 \mathrm{~m}$ from the centre of the CS725 measurement area and approximately $16 \mathrm{~m}$ from the centre of the SSG1000. In 2014/15, after the CS725 was moved, the manual sampling was done approximately $6 \mathrm{~m}$ from the
CS725 measurement area and approximately $25 \mathrm{~m}$ from the SSG1000.

An ESC-30 snow tube was used at the Fortress Mountain site. A full snow survey was conducted at the site once per month, transitioning to bi-weekly during the ablation period. Although the actual snow survey course was through the forested area, supplemental measurements were taken in the clearing where the instrumentation is located. The distance between the sensor and the manual measurements was approximately $10 \mathrm{~m}$.

The manual SWE measurements at Weissfluhjoch were performed bi-weekly on the SLF study plot using a bulk density aluminum sampling tube with a sampling area of $70 \mathrm{~cm}^{2}$ and length of $55 \mathrm{~cm}$. The weight was measured with a cradle and balance (Jonas et al., 2009). The distance between the sensor and manual snow measurement varied from observation to observation as the location of the snow pit was relocated for each bi-weekly measurement. The average distance was approximately $20 \mathrm{~m}$.

\subsection{Intercomparisons}

The intercomparisons are not completely consistent amongst the four sites because of the different instrumentation and manual methods for measuring reference SWE. At Sodankylä and Weissfluhjoch, the sensors can both be compared with the manual SWE measurements made nearby, although the manual measurements are not within the measuring area of either instrument. The timestamps of both instruments were matched as closely as possible to the manual observation time. Since the CS725 only reports every $6 \mathrm{~h}$, the measurement output closest to the manual observation time was used for the intercomparison. Since the SSG1000 reports every minute, no time adjustment was necessary. The same procedure was used to compare the CS725 to the SSG1000. No SSG1000 was present at Caribou Creek or Fortress Mountain and no CS725 sensors were installed at Weissfluhjoch.

For the CS725, which outputs a SWE value derived from both the $\mathrm{K}$ and $\mathrm{Tl}$ counts, the manufacturer suggests that the output with the higher count is generally the most reliable. For Sodankylä, the K / Tl ratio is always greater than 1 (varying from 3.5 to 8.0 ), indicating that the potassium counts are greater than the thallium counts. For Caribou Creek, the ratio varies from 2.8 to 4.0. For Fortress Mountain, the ratio varies from 0.3 to 8.5 but is above 1 approximately $70 \%$ of the time. Therefore, the CS725 analysis is based on the potassium output although the statistics for thallium are shown in parenthesis in Table 1. This will allow us to determine if there were any obvious differences in the statistics related to the output derived from one source or the other. 

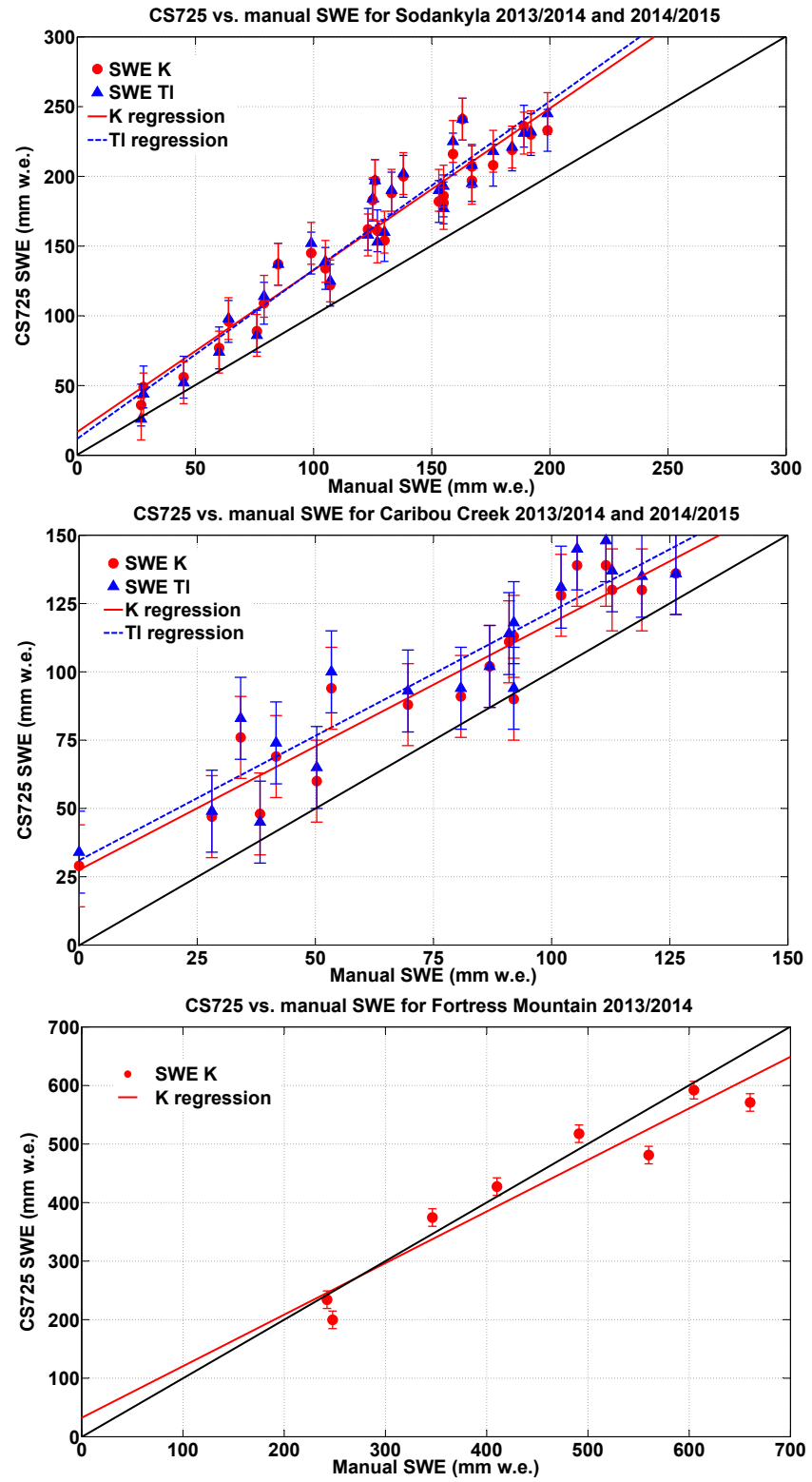

Figure 3. CS725 vs. manual SWE for Sodankylä (top) and Caribou Creek (middle) for the 2013/14 and 2014/15 seasons and Fortress Mountain (bottom) for the 2013/14 season. Potassium output in red and thallium output in blue. Black line is $1: 1$. Error bars represent manufacturer's stated sensor accuracy.

\section{Results}

\subsection{CS725 vs. manual}

The comparison between the CS725 measurements and the manual SWE observations are shown in Fig. 3 with the potassium output in red circles and the thallium output in blue triangles. The black line in the figure represents the $1: 1$ line and the error bars represent the manufacturer's stated sensor accuracy. Figure 4 shows the time series of automated and
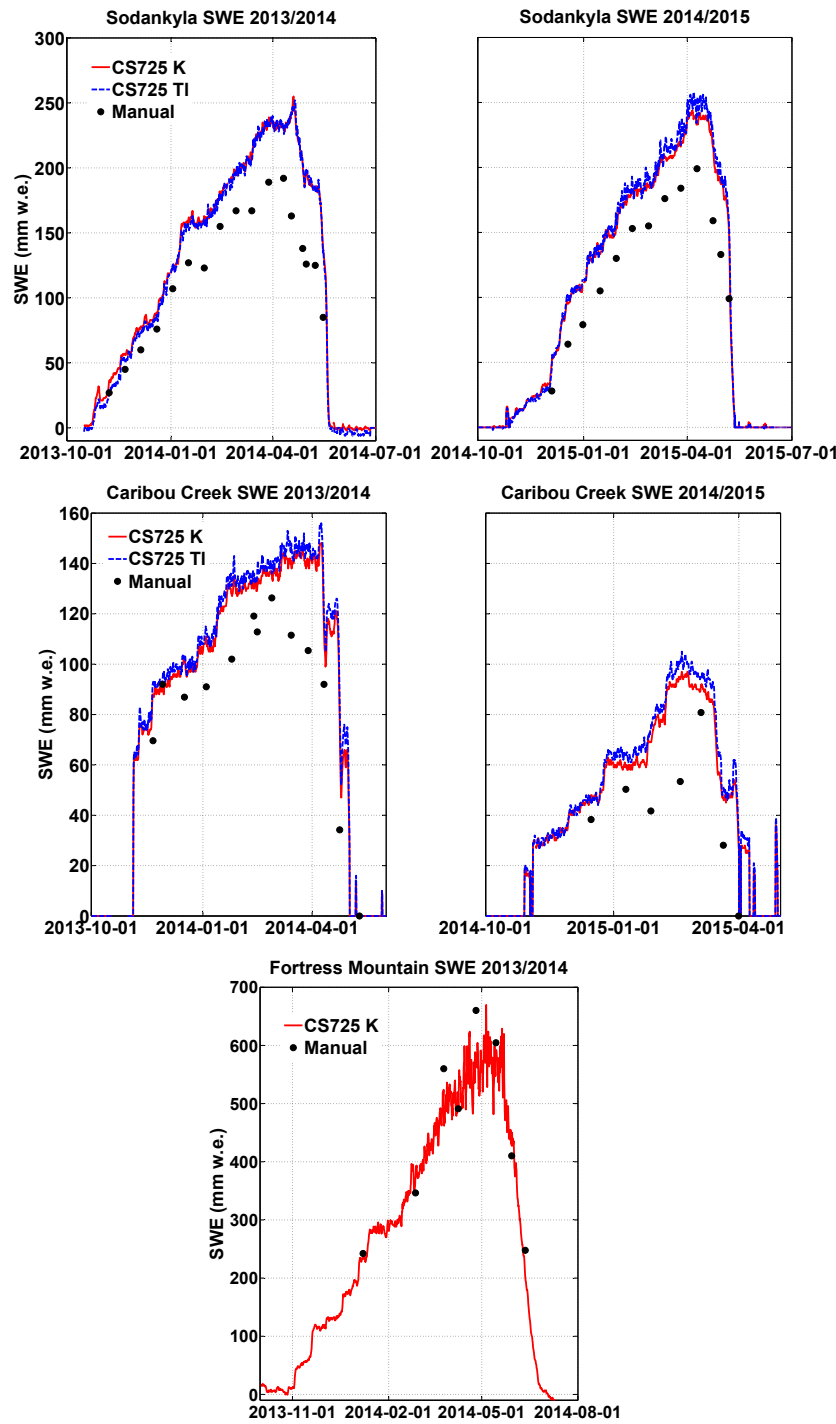

Figure 4. Time series of the CS725 SWE sensors and manual SWE measurements at Caribou Creek (top), Sodankylä (middle) for the 2013/14 (left) and 2014/15 (right) seasons, and Fortress Mountain (bottom) for the 2013/14 season.

manual SWE measurements. Figure 5 shows the difference between the CS725 and the manual measurement (red) and the measured air temperature (blue) through the two seasons. The regression analysis coefficients and summary statistics are listed in Table 1. The statistics are provided for each individual season and for the two seasons combined. The statistics for the individual seasons are also refined further to show results for the accumulation period (delineated from the ablation period by the timing of maximum seasonal SWE). This will help to eliminate the effects of snowmelt on both the manual measurement and the various potential impacts on the CS725 measurement. These figures and tables are further analyzed for each site in the following subsections. 
Table 1. Regression coefficients and other statistical measures for the multi-season intercomparison of the CS725 with manual SWE at Sodankylä, Caribou Creek and Fortress Mountain (where $\beta$ and $\varepsilon$ are the slope and intercept of the regression line). Values inside and outside of the parenthesis represent thallium and potassium output, respectively, from the sensor. "Accumulation" indicates that data occurring after maximum seasonal SWE is omitted from the analysis. "Combined" indicates that data from both seasons are included, and $n$ represents the sample size.

\begin{tabular}{|c|c|c|c|c|c|c|c|}
\hline Site & Season & $\beta$ & $\begin{array}{r}\varepsilon \\
\text { mm w.e. }\end{array}$ & $r^{2}$ & $\begin{array}{l}\text { RMSE } \\
\text { mm w.e. }\end{array}$ & $\begin{array}{r}\text { Mean relative } \\
\text { bias } \%\end{array}$ & $n$ \\
\hline \multirow{5}{*}{ Sodankylä } & $2013 / 14$ & $1.24(1.27)$ & $8.77(3.17)$ & $0.92(0.92)$ & $43.0(42.2)$ & 30.1 & 17 \\
\hline & $\begin{array}{l}\text { 2013/14 } \\
\text { (accumulation) }\end{array}$ & $1.24(1.28)$ & $0.0123(-6.63)$ & $0.97(0.97)$ & $35.6(33.9)$ & 24.6 & 13 \\
\hline & $2014 / 15$ & $1.06(1.13)$ & $26.9(24.2)$ & $0.96(0.96)$ & $36.6(42.2)$ & 30.9 & 13 \\
\hline & $\begin{array}{l}2014 / 15 \\
\text { (accumulation) }\end{array}$ & $1.05(1.12)$ & $23.3(20.2)$ & $0.99(0.99)$ & $30.0(35.7)$ & 28.1 & 10 \\
\hline & Combined & $1.16(1.21)$ & $16.8(11.9)$ & $0.92(0.92)$ & $40.3(42.2)$ & 30.4 & 30 \\
\hline \multirow{5}{*}{ Caribou Creek } & $2013 / 14$ & $0.783(0.764)$ & $40.6(46.9)$ & $0.78(0.72)$ & $22.8(27.5)$ & 22.2 & 12 \\
\hline & $\begin{array}{l}2013 / 14 \\
\text { (accumulation) }\end{array}$ & $0.982(0.997)$ & $17.7(20.2)$ & $0.79(0.75)$ & $18.0(22.2)$ & 15.4 & 9 \\
\hline & $2014 / 15$ & $0.849(0.849)$ & $27.1(30.4)$ & $0.77(0.71)$ & $23.6(27.4)$ & 63.0 & 7 \\
\hline & $\begin{array}{l}2014 / 15 \\
\text { (accumulation) }\end{array}$ & $1.12(1.31)$ & $-8.38(-14.5)$ & $0.55(0.60)$ & $25.4(29.5)$ & 42.4 & 4 \\
\hline & Combined & $0.904(0.911)$ & $27.5(31.0)$ & $0.90(0.87)$ & $23.1(27.4)$ & 34.6 & 19 \\
\hline \multirow{2}{*}{ Fortress Mountain } & $2013 / 14$ & 0.881 & 32.4 & 0.92 & 48.0 & -4.5 & 8 \\
\hline & $\begin{array}{l}\text { 2013/14 } \\
\text { (accumulation) }\end{array}$ & 0.764 & 84.4 & 0.94 & 56.0 & -3.6 & 5 \\
\hline
\end{tabular}

\subsubsection{Sodankylä}

Throughout the intercomparison periods at Sodankylä, the CS725 overestimated SWE on average by $30 \%$ (mean relative bias or MRB) as compared to the manual measurements. From Table 1, the regression analysis for the CS725 as compared to manual SWE over the entire season results in a slope $(\beta)$ of 1.24 for $2013 / 14$ and 1.06 for $2014 / 15$. The difference in $\beta$ between the $\mathrm{K}$ and $\mathrm{Tl}$ outputs is small. The intercepts $(\varepsilon)$ for the entire seasons are $8.77 \mathrm{~mm}$ w.e. for $2013 / 14$, increasing to $26.9 \mathrm{~mm}$ w.e. for $2014 / 15$. This difference might be in part a result of moving the instrument to a new location. The correlation coefficient, $r^{2}$, is 0.92 for $2013 / 14$ and 0.96 for $2014 / 15$. With the period of ablation eliminated from the analysis, the impact on $\beta$ and $\varepsilon$ are relatively small although the intercept $\varepsilon$ decreases almost 9 and $4 \mathrm{~mm}$ w.e. for the respective seasons. The accumulation period $r^{2}$ increases to 0.97 and 0.99 for the $2013 / 14$ and $2014 / 15$ seasons, respectively, suggesting that more scatter is introduced into the relationship during the ablation period. This is discussed further below.
Figure 4 (top) shows the time series for the 2013/14 (left) and 2014/15 (right) seasons at Sodankylä. In this figure, the overestimation of the CS725 (red and blue lines) can be seen when compared to manual SWE (black circles). In general, the instrument trends are the same as for the manual measurements with differences between the measurements increasing after the start of the ablation periods and in January 2014 and December 2014. Although it appears from Fig. 5 that the difference between the measurements is simply increasing with time (or SWE amount), we believe that at least part of this increase is a result of melting in the snowpack which occurs during some relatively warm days. In 2013/14 (Fig. 5, left), a large increase in the difference occurs after the $>0{ }^{\circ} \mathrm{C}$ temperatures in mid- to late April. In 2014/15 (Fig. 5, right), there is a moderate increase after some $>0{ }^{\circ} \mathrm{C}$ temperatures in March but a much larger jump after the beginning of the ablation period in April.

\subsubsection{Caribou Creek}

The comparison of the CS725 instrument and the manual SWE measurements made at Caribou Creek are shown in Fig. 3 (middle) and summarized in Table 1. As with Sodankylä, the difference between the two sensor outputs 
(potassium vs. thallium) is negligible. Also like Sodankylä, the CS725 at Caribou Creek consistently overestimates total SWE such that the MRB is $35 \%$. However, the relationships between the instrument and the manual SWE measurements are different than at Sodankylä. At Caribou Creek, the slopes of the regression line, $\beta$, are less than 1 for all scenarios in Table 1 with the exception of the accumulation period in 2014/15. The intercepts $(\varepsilon)$ are all larger than seen at Sodankylä, with the accumulation period in $2014 / 15$ being the exception once again. The $r^{2}$ values range from 0.90 for the combined (2013/14 and 2014/15) data to 0.55 for the accumulation period in $2014 / 15$.

For both the 2013/14 and 2014/15 seasons, the time series for Caribou Creek (Fig. 4, middle) shows a rapid increase in SWE in early winter related to heavier, wet snowfall events that most likely began as rain and transitioned to snow. For 2013/14, the CS725 time series generally follows the trend of the manual SWE measurements with a large deviation developing mid- to late March with the onset of seasonal ablation. Figure 5 (middle) shows the time series of the difference between the CS725 and manual SWE (red) and the temperature time series (blue) for both seasons. In 2013/14 (Fig. 5, middle left), there is an increase in the difference that occurs in late January. This could be due to a melt period where temperatures at the site exceeded $4{ }^{\circ} \mathrm{C}$ preceding the increase in the instrument bias. A much larger jump in the difference occurs mid-March possibly due to significantly higher temperatures (exceeding $10^{\circ} \mathrm{C}$ ) earlier that month. In 2014/15 (Fig. 5, middle right), the deviation between the measurements occurs earlier in the season (mid- to late January) coinciding with a January snowmelt period characterized by above $0{ }^{\circ} \mathrm{C}$ air temperatures and high wind speeds (not shown) that resulted in ice layers on top and within the snowpack (which make accurate manual SWE measurements more difficult) and possibly infiltration of meltwater into the frozen sandy soil. Differences decrease after snowfall events in February only to increase again after the start of ablation in March.

In reaction to an observed offset after the 2013/14 intercomparison season, soil moisture and temperature probes were installed at the Caribou Creek site with the objective of correlating post-calibration, overwinter and ablation soil moisture changes with sensor offsets. The instruments were installed at three depths: $0-5 \mathrm{~cm}$ (vertically), $5 \mathrm{~cm}$ (horizontally) and $20 \mathrm{~cm}$ (horizontally). Unfortunately, the probes only measure liquid water (volumetric water content, or VWC) so the analysis is mostly limited to when the soil temperatures (also measured by the probe) are above $0^{\circ} \mathrm{C}$ when we assume that most of the water in the soil is unfrozen.

Figure 6 shows the time series of soil moisture near the surface $(0-5 \mathrm{~cm})$ along with the difference between the CS725 and manual measurements (scaled by a factor of 100 for visualization) for the 2014/15 season. The red markers indicate when the soil temperature at this level is above $0^{\circ} \mathrm{C}$. It is easy to see from the time series when the liquid soil moisture (near the surface) freezes in late fall, resulting in
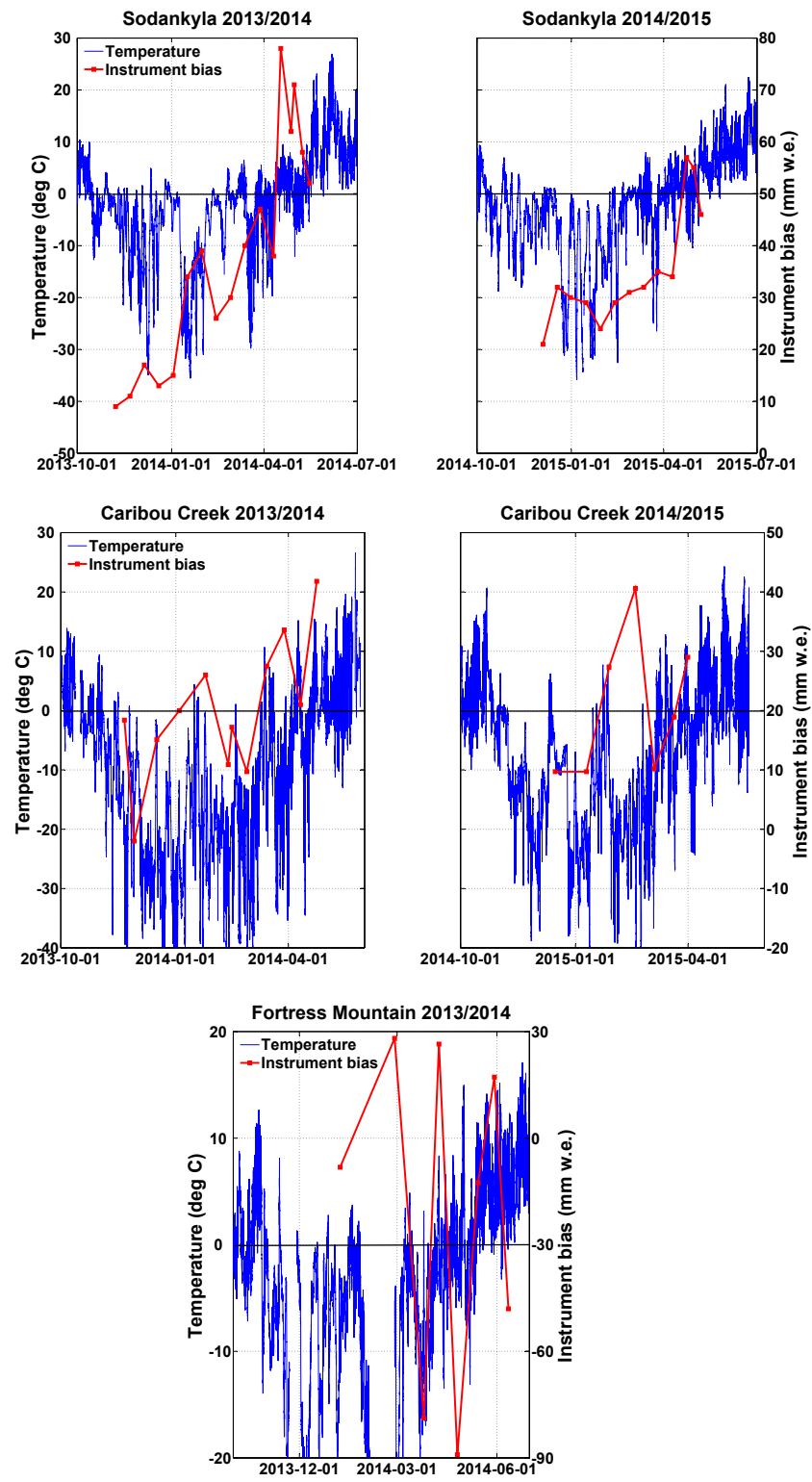

Figure 5. Time series of $1.5 \mathrm{~m}$ air temperature (blue, left axis) and difference between CS725 and manual measurements (red, right axis) at Sodankylä (top) and Caribou Creek (middle) for the 2013/14 (left) and 2014/15 (right) seasons and at Fortress Mountain (bottom) for the 2013/14 season.

a rapid drop in measured VWC. Following the freezing of the near-surface layer, which occurs on 8 November 2014, the measured soil moisture in this layer remains static until mid-March 2015, when a period of positive air temperatures (Fig. 5, middle right) raises the near-surface soil temperatures above freezing, transitioning frozen soil moisture to liquid and allowing for further infiltration of snowmelt water into the sandy soil. The near-surface $(0-5 \mathrm{~cm})$ soil temperatures rose above freezing even with snow on the surface. The snowpack was patchy (verified from hourly photos) and shal- 


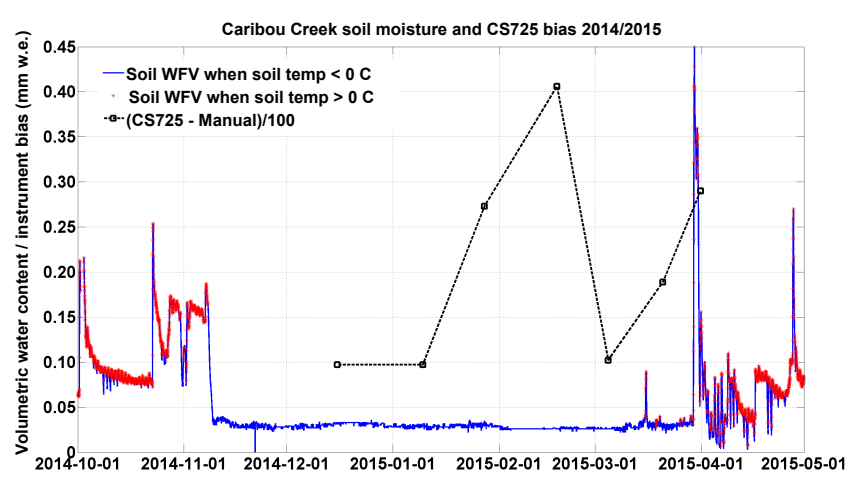

Figure 6. Time series of near-surface $(0-5 \mathrm{~cm})$ soil moisture (volumetric water content, blue) and the difference between the CS725 and manual measurements (dashed line and black boxes) at Caribou Creek for the 2014/15 season. Red markers show where nearsurface soil temperatures are above $0{ }^{\circ} \mathrm{C}$.

low, and meltwater was likely percolating through the snow and into the top layers of the soil.

The freezing of the $0-5 \mathrm{~cm}$ depths in early November is preceded by rain-snow events in late October that are represented by the large jump in CS725 SWE shown in Fig. 4 (middle right) and confirmed with snow depth measurements (not shown). During the transition from rain to snow and prior to the surface freezing, Fig. 6 shows fluctuations in near-surface soil moisture (measured by the soil moisture sensor as VWC) related to the precipitation events in late October and early November. The soil moisture calibration of the CS725 sensor was entered as a gravimetric water content (GWC) of 0.10 , which can be converted to VWC by multiplying by the specific gravity of the soil (Lambe and Whitman, 1969). The specific gravity of the loose sand near the surface at Caribou Creek was estimated to be 1.4 based on nearby measurements taken during the BOREAS campaign (Anderson, 2000). The increase in measured VWC from the calibration value to 0.18 (GWC of 0.13 ) prior to freezing has the potential to create a small but potentially perpetuating offset of up to $3 \mathrm{~mm}$ w.e. in the CS725 SWE estimates and may explain at least some of the bias shown by the instrument beginning in mid-December.

In addition to the offset in the CS725 SWE measurements that occurs at the beginning of the season, it was anticipated that the rapid increase in the difference between the CS725 and manual SWE at the end of January 2015 could also be attributed to a change in near-surface soil moisture, as this was a time of mid-season snowmelt. However, a change in the liquid soil moisture during the melt period could not be detected by the soil moisture sensors so it is unlikely that the increase in the instrument offset can be attributed to infiltration of meltwater into the sandy soil. A more plausible explanation is manual measurement errors that could result from attempting to sample a complex snowpack containing ice layers in the pack or at the snow-soil interface. Ice lay- ers would have formed due to mid-season melt and refreezing. The increase in the difference between the manual measurement and CS725 in mid- to late March could be a result of snowmelt infiltrating into the top layers of the sandy soil as the soil thaws or forming a basal ice layer (Woo et al., 1982; Lilbaek and Pomeroy, 2008) on top of the soil. A corresponding spike in measured soil moisture during early spring snowmelt is shown in Fig. 6.

\subsubsection{Fortress Mountain}

The intercomparison of the CS725 instrument and the manual SWE measurements made at Fortress Mountain are shown in Fig. 3 (bottom) and summarized in Table 1. Unlike the other two sites, the CS725 and manual SWE measurements generally fall on the $1: 1$ line with no systematic overestimation (MRB $<-5 \%$ ). This can also be seen in the time series shown in Fig. 4 (bottom). The slope of the regression line is 0.88 with a small decrease to 0.76 when excluding the ablation period. The intercept is $32.4 \mathrm{~mm}$ w.e. increasing to $84.4 \mathrm{~mm}$ w.e. when excluding the ablation period. The $r^{2}$ is comparable to Sodankylä at 0.92 (increasing to 0.94 by excluding the ablation period). It is unfortunate that the sample size is relatively small $(n=8)$ but, regardless, the instrument compares quite well to the manual measurements at this site.

\subsection{SSG1000 vs. manual}

The regression analysis for the SSG1000 intercomparisons is shown in Fig. 7 with the time series for both seasons shown in Fig. 8. The comparison statistics are in Table 2. This analysis, as for the CS725 above, is organized by site.

\subsubsection{Sodankylä}

The SSG1000 regression analysis with the manual SWE measurements shown in Fig. 7 (top) and summarized in Table 2 has an $r^{2}$ for the entire 2014/15 period of 0.99 but is only 0.84 for the $2013 / 14$ period. However, the SWE data from the SSG1000 are not available for the ablation period in 2014/15 due to an instrument malfunction. To have a consistent intercomparison for the two seasons, the ablation period (post maximum SWE) was removed from the 2013/14 period and the $r^{2}$ becomes 0.97 , very similar to 2014/15. Combining the two seasons, the slope of the regression, $\beta$, becomes 0.99 with an offset $\varepsilon$ of $-7.27 \mathrm{~mm}$ w.e. with an $r^{2}$ of 0.88 . The MRB for the two seasons combined is $-11 \%$.

The time series of these data are shown in Fig. 8 (top) for both the 2013/14 (left) and 2014/15 (right) seasons. For both seasons, the sensor measurements track quite well with the manual measurements. The outliers that appear in Fig. 7 (top) can also be seen in the 2013/14 time series (Fig. 8, top left) beginning midway through the ablation period. It is unknown whether this occurs during the 2014/15 ablation period because the data are missing due to a sensor failure caused by 
Table 2. Regression coefficients and other statistical measures for the multi-season intercomparison of the SSG1000 with manual SWE at Sodankylä and Weissfluhjoch (where $\beta$ and $\varepsilon$ are the slope and intercept of the regression line). "Combined" indicates that data from both seasons are included and $n$ indicates the sample size.

\begin{tabular}{llrrrrrr}
\hline Site & Season & $\beta$ & $\begin{array}{r}\varepsilon \\
\text { mm w.e. }\end{array}$ & $r^{2}$ & $\begin{array}{r}\text { RMSE } \\
\text { mm w.e. }\end{array}$ & $\begin{array}{r}\text { Mean relative } \\
\text { bias } \%\end{array}$ & $n$ \\
\hline \multirow{3}{*}{ Sodankylä } & $2013 / 14$ & 1.05 & -15.5 & 0.84 & 24.2 & -15.1 & 17 \\
& $2014 / 15$ & 0.92 & 5.5 & 0.99 & 7.9 & -2.3 & 10 \\
& Combined & 0.99 & -7.3 & 0.88 & 19.8 & -10.8 & 27 \\
\hline \multirow{3}{*}{ Weissfluhjoch } & $2013 / 14$ & 0.72 & 91.7 & 0.97 & 55.5 & 4.2 & 14 \\
& $2014 / 15$ & 0.82 & 79.0 & 0.97 & 58.6 & 11.3 & 17 \\
& Combined & 0.79 & 77.2 & 0.96 & 57.2 & 8.1 & 31 \\
\hline
\end{tabular}
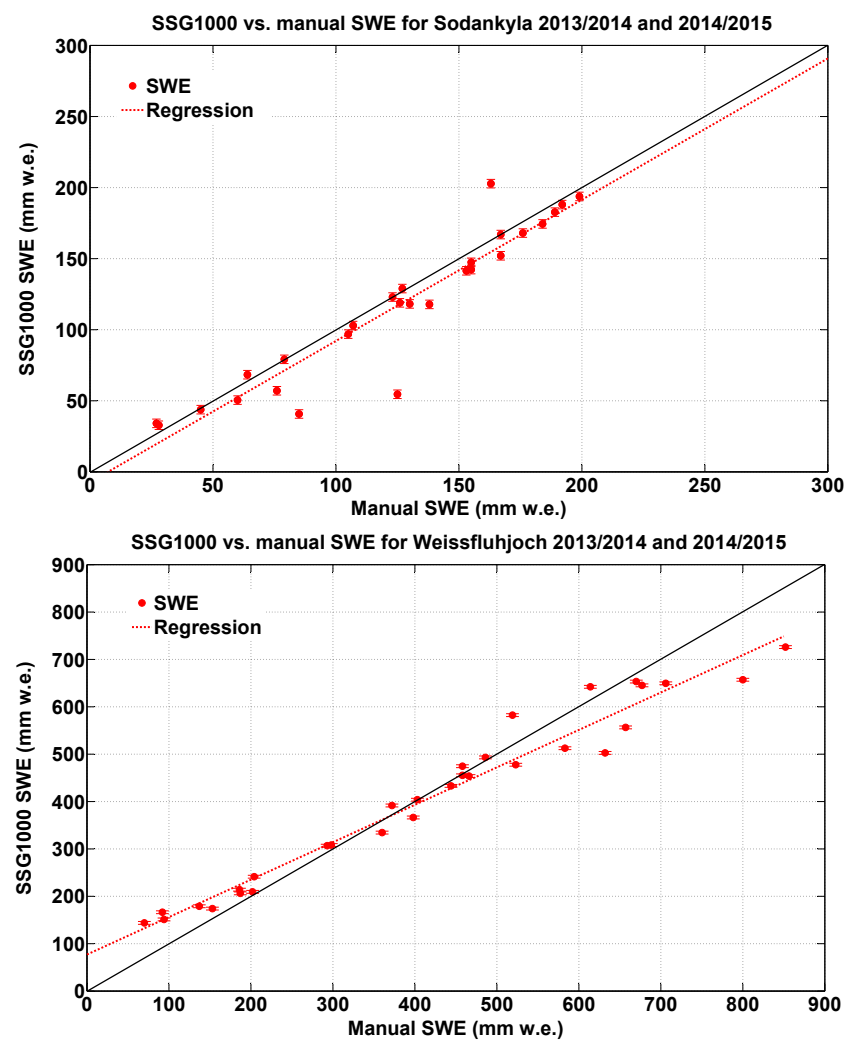

Figure 7. SSG1000 vs. manual SWE at Sodankylä (top) and Weissfluhjoch (bottom) for the 2013/14 and 2014/15 seasons. Black line is $1: 1$. Error bars represent manufacturer's stated sensor accuracy.

water damage to the electronics (an issue later remedied by the manufacturer).

\subsubsection{Weissfluhjoch}

The regression analysis for the SSG1000 and the manual SWE measurements is shown in Fig. 7 (bottom) with the time series in Fig. 8 (bottom). This alpine site has a much deeper snowpack than either Caribou Creek or Sodankylä but comparable to Fortress Mountain, which unfortunately

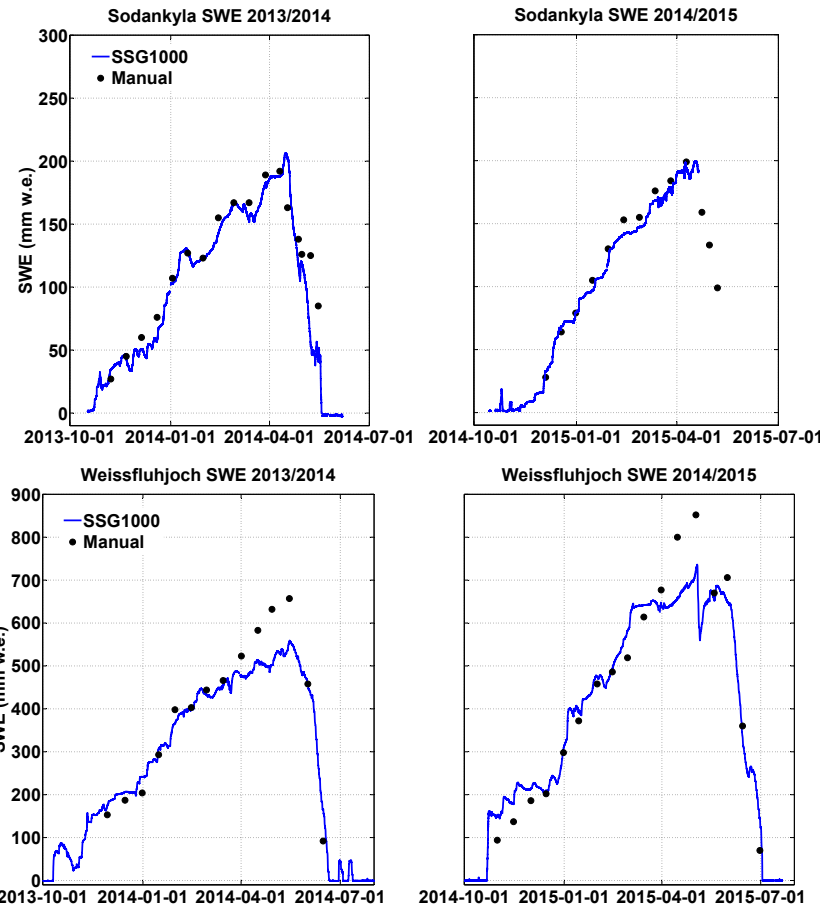

Figure 8. Time series of the SSG1000 SWE sensors and manual SWE measurements at Sodankylä (top) and Weissfluhjoch (bottom) for the 2013/14 (left) and 2014/15 (right) seasons.

did not have concurrent SSG1000 measurements. The $r^{2}$ for both seasons is quite high at 0.97 , similar to the accumulation period intercomparison at Sodankylä, but $\beta$ is less $(0.72$ and 0.82 ) and $\varepsilon$ is much higher ( 91.7 and $79.0 \mathrm{~mm}$ w.e.) for both seasons (2013/14 and 2014/15). The outliers are obvious in Fig. 8 (bottom) when the manual SWE measurements are substantially higher than the sensor measurements. Unlike Sodankylä, these outliers mostly occur before maximum seasonal SWE, which is why we do not break the season down as we do with Sodankylä. They are, however, likely a result of sensor bridging which is discussed more in Sect. 4. There are also outliers that occur late in the ablation periods, where the sensor substantially overestimates SWE, and 
Table 3. Regression coefficients for the multi-season intercomparison of the CS725 with the SSG1000 SWE measurements at Sodankylä (where $\beta$ and $\varepsilon$ are the slope and intercept of the regression line). "Accumulation" indicates that data occurring after maximum seasonal SWE are omitted from the analysis.

\begin{tabular}{lrrr}
\hline Season & $\beta$ & $\begin{array}{r}\varepsilon \\
\text { (mm w.e.) }\end{array}$ & $r^{2}$ \\
\hline $2013 / 14$ & 1.20 & 15.7 & 0.90 \\
$2013 / 14$ & 1.24 & 4.29 & 0.98 \\
(accumulation) & 1.19 & 11.9 & 0.99 \\
\hline $2014 / 15$ & 1.19 & & \\
\hline
\end{tabular}

these are perhaps due to issues with the manual sampling of a complex (melting or melting-refreezing) snowpack. When combining the two seasons, the resulting low MRB of $8 \%$ (for combined seasons) is somewhat surprising given the obvious outliers. Perhaps the low combined MRB is a reflection of errors in one season compensating the errors in the other season.

\subsection{CS725 vs. SSG1000}

The intercomparison with manual measurements for both the CS725 and the SSG1000 suggests that the agreements are the most favourable during accumulation rather than during ablation. Figure 7 shows the relationship between the CS725 and the SSG1000 for both seasons at Sodankylä with the 2014/15 season shown in red circles and the 2013/14 season shown in blue dots (changing to blue triangles at the approximate onset of ablation). The relationship for both years appears to be linear up to the time when maximum SWE is reached. At the onset of ablation, the relationship between the instruments (shown by the blue triangles) deviates substantially from linear. This is confirmed by Table 3, which shows a higher $r^{2}$ when the 2013/14 ablation period is not included in the analysis. This analysis could only be completed for the 2013/14 season since the sensor data are missing for the 2014/15 ablation period due to malfunction.

\subsection{Sensor reliability}

Data quality control metrics for the CS725 sensors at each of the two SPICE sites demonstrated that the instruments performed at a high level of reliability, such that over $95 \%$ of the sensor measurements were usable for intercomparison. No malfunctions were noted and no maintenance was required at any of the sites.

For the SSG1000, data quality control metrics show that the sensors performed reliably during the accumulation periods but malfunctioned at Sodankylä late in the spring of 2014 and again early spring of 2015. At Weissfluhjoch, $99 \%$ of the $1 \mathrm{~min}$ data were usable for intercomparison. At Sodankylä, the malfunctions resulted in only 83 and $67 \%$ of the $1 \mathrm{~min}$ data, for the 2013/14 and 2014/15 seasons, respectively, being available for intercomparison. The sensor malfunctions at Sodankylä were determined to be related to water damage to the electronics. Other than this, no other malfunctions were reported or maintenance required during the intercomparison.

\section{Discussion}

The regression analysis between the CS725 and the manual SWE measurements resulted in $r^{2}$ values ranging from 0.55 to 0.99 , depending on site and season. Combined season $r^{2}$ values ranged from 0.90 to 0.92 . Although generally lower than the correlations of 0.99 reported for intercomparisons with other instruments by Wright et al. (2011), our correlations (averaged by season) are similar to the $r^{2}$ of 0.83 that they reported for snow tube measurements. The (combined season) bias shown here, which was between 30 and $35 \%$, is substantially higher than the $18 \%$ reported by Choquette et al. (2008). The exception to this is the CS725 at Fortress Mountain which has a mean negative bias less than $5 \%$ when compared to the manual measurements. Besides the maximum SWE, the two major differences that Fortress Mountain has from Caribou Creek and Sodankylä are the soil and the topography. Soils at the Fortress Mountain site have higher clay and loam content, overlain with a layer of organics, and generally remain frozen and saturated for the duration of the winter. These, combined with the sloping terrain and faster meltwater runoff via drainage channels, likely minimizes the change in soil moisture during the transition seasons and thereby minimizes potential offsets in the CS725 measurements. Furthermore, the correlations for the CS725 for Caribou Creek are substantially lower than for Sodankylä and Fortress Mountain. This could be for several reasons. The spatial and seasonal variability are quite high at Caribou Creek and the sample size is low. This is especially the case for 2014/15 where sample size is small due to a shorter and more variable winter where melt and refreeze occurred several times over the course of the season (Fig. 5, middle right). Melting and refreezing generally makes the manual SWE measurements more difficult and prone to error, creates basal ice and results in higher spatial variability. Eliminating the ablation period improved the comparison statistics for 2013/14 but made the statistics for 2014/15 much worse due to the reduced sample size. Potential sources of error in the CS725 intercomparison are discussed further in the following sections.

The SSG1000 was quite highly correlated with the manual SWE measurements at both Sodankylä and Weissfluhjoch with $r^{2}$ values as high as 0.99 at Sodankylä (when excluding the ablation period) and 0.97 at Weissfluhjoch. However, when the ablation period is included in the intercomparison for 2013/14 at Sodankylä (it is not present in 2014/15 at Sodankylä due to sensor malfunction), the $r^{2}$ drops to 0.84 . The 
more significant result at Sodankylä is the smaller MRB as compared to the CS725, which is -2 to $-15 \%$ (depending on the exclusion of ablation). The magnitude of the MRB is similar at Weissfluhjoch but the bias here is a positive $8 \%$. This is surprising considering the many occurrences of negative sensor bias (as seen in Fig. 8, bottom) but these negative outliers are balanced by some large (albeit inconspicuous) positive outliers at the end of the ablation periods. The outliers for Sodankylä in Fig. 7 (top) occur during the ablation period in late April-May 2014 but it is difficult to ascertain whether the errors are related to the instrument or to the manual measurement. The most likely explanation is that these are related to the occurrence of bridging. Bridging is also suspected as the cause of the pre-ablation outliers at Weissfluhjoch since the sensor seems to agree quite well with the manual measurements up to mid-March and early April for both seasons. An intercomparison with a collocated snow pillow (not shown here) suggests a similar albeit smaller negative bias during the same period. Errors associated with bridging are discussed further in this section.

The CS725 and SSG1000 measurements at Sodankylä correlate very well with each other showing correlations as high as 0.99 when excluding the ablation periods. The key result here, as shown in Fig. 9, is the deviation from this linear correlation at the onset of melt in the 2013/14 season. Although some of this deviation can be blamed on differential melting at the site, we attribute a large portion of the deviation to the different measurement principles of the sensors. At the onset of melt and the ripening of the snowpack, meltwater drains out of the snowpack towards the ground surface. Once reaching the surface, the meltwater can pool and refreeze (potentially forming a basal layer of ice), runoff from the measurement area or infiltrate into the soil. Due to the flat measurement area and the sandy soil at Sodankylä, runoff is unlikely; therefore the meltwater is either infiltrating into the sandy soil or refreezing at the surface. Either way, the same meltwater is likely draining through and away from the measurement plate of the SSG1000 and therefore no longer being measured as SWE in the snowpack. However, this meltwater, whether infiltrated into the top layer of the sandy soil or pooling at the surface, is still being registered by the CS725 as SWE. This contributes to the overestimation of SWE by the CS725 as compared to the SSG1000 and to the non-linearity of the intercomparison shown in Fig. 9 after ablation. Also, this meltwater is either difficult or impossible to include in a snow tube sample, increasing the bias between the CS725 and the manual measurements.

\subsection{Sources of error}

There are several possible sources of error that affect both the automated and manual SWE measurements. They are discussed and analyzed for each instrument and method in this section.

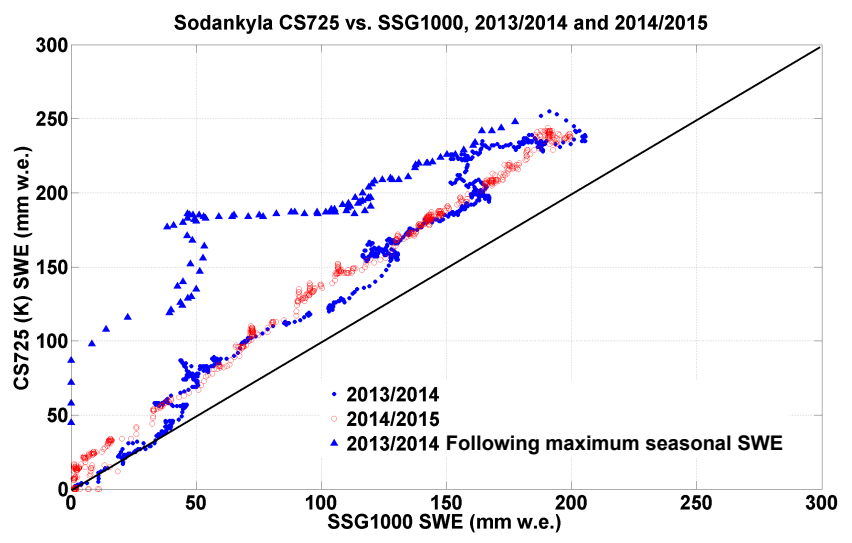

Figure 9. CS725 vs. SSG1000 for the 2013/14 (blue dots/blue triangles) and 2014/15 (red) seasons at Sodankylä. Black line is $1: 1$.

\subsubsection{Soil moisture (CS725)}

A potential source of error for the CS725 can arise from a poor pre-snowpack soil moisture calibration or a large postcalibration change in soil moisture prior to the freezing of the ground surface. Overwinter soil moisture changes (Gray et al., 1985) or infiltration of snowmelt water into soils (Gray et al., 2001) could also result in deviation between the manual and CS725 SWE measurements. Since the CS725 calculation of SWE is based on gamma ray counts during wet and dry periods with no snow cover, incorrect measurements or faulty assumptions with respect to the soil moisture calibrations could result in a sensor offset. Furthermore, if soil moisture levels change significantly prior to freeze-up, during winter or during ablation, then the SWE estimates derived from the sensor are less reliable. The approximate error associated with an inaccurate gravimetric soil moisture calibration, as provided by the manufacturer, is roughly $10 \mathrm{~mm}$ w.e. of SWE for a 0.10 change in GWC. Figure 6 shows an increase in soil moisture at Caribou Creek up to a VWC of 0.18 (GWC of 0.13) prior to freeze-up in the fall of 2014, an increase of $0.03 \mathrm{GWC}$ and approximately $3 \mathrm{~mm}$ w.e. The resulting calibration offset could explain up to $30 \%$ of the early season difference between the instrument and the manual measurement shown in Figs. 4 (middle right) and 5 (middle right). This calibration issue would then perpetuate through the winter period and grow with any additional infiltration into the soil beneath the snowpack. It is unfortunate that this same soil moisture and soil temperature data are not available for Sodankylä or for the first season at Caribou Creek as this would have provided some verification for the calibration offset.

From Fig. 6, there appears to be a coinciding jump in the CS725 bias and the jump in soil moisture (due to above freezing soil temperatures and infiltration) in the spring of 2015 at Caribou Creek. Although the bias is not as large as that seen in midwinter, it is a significant increase of ap- 
proximately $10 \mathrm{~mm}$ w.e. for each of the final two intercomparison points in mid-March and early April. Much of this $20 \mathrm{~mm}$ w.e. increase could be explained by a corresponding increase in soil moisture from $0.18 \mathrm{VWC}(0.13 \mathrm{GWC}$; estimated at freeze-up) to $0.45 \mathrm{VWC}(0.32 \mathrm{GWC}$; spike at thaw) or approximately $19 \mathrm{~mm}$ w.e., assuming that the CS725 is interpreting this near-surface soil moisture as SWE.

There is some ambiguity in the soil moisture results because the soil moisture sensors are incapable of measuring moisture content below $0{ }^{\circ} \mathrm{C}$ and because this is not the only source of error. However, we think that these soil measurements are useful for explaining at least some of the offsets seen between the sensor and the manual SWE measurements, especially during the transition periods. More work is needed on these linkages before a reliable sensor adjustment can be derived.

\subsubsection{Ice bridging (SSG1000)}

Ice bridging is a known issue affecting SWE measurements that are made by weight, such as snow pillows or the snow scale (e.g. Engeset et al., 2000). Bridging typically occurs when air temperature reaches $0{ }^{\circ} \mathrm{C}$ and then cools creating a melt-refreeze crust layer on the snow surface. This layer is very hard and supports the weight of the snow, thus causing an underestimate of measured SWE with further accumulation on the surface. Probable bridging situations can be seen in Fig. 7 both at Sodankylä and at Weissfluhjoch. At Sodankylä, in December 2013, March 2014 and FebruaryMarch 2015, the SWE values measured by the SSG1000 do not increase as quickly as the manual measurements. At the same time, air temperature first goes above $0{ }^{\circ} \mathrm{C}$ and then cools to as low as $-30^{\circ} \mathrm{C}$ creating perfect conditions for ice bridging. At Weissfluhjoch, the cause of potential ice bridging is not so obvious, but it is difficult to explain the differences between manual and SSG1000 measurements otherwise. The snowpack was homogeneous (verified with terrestrial laser scans) and even though a co-located snow pillow (not shown here) showed some underestimation compared to the manual measurements, the underestimation was much smaller than by the SSG1000. However, snow pillows have been found to be less prone to ice bridging issues due to their larger surface area (Beaumont, 1966b; Tollan, 1970). A more comprehensive description of the physical processes that cause measurement errors in SWE pressure sensors can be found in Johnson (2004).

\subsubsection{Snow spatial variability}

Another potential source of error in this analysis is due to the spatial variability at the intercomparison sites impacting the relative SWE between the sensor and manual measurement locations. At Sodankylä, the maximum distance between the sensors and the manual SWE measurements was $12 \mathrm{~m}$ for the CS725 (6 m after the move prior to the 2014/15 sea- son) and $25 \mathrm{~m}$ (16 m in 2013/14) for the SSG1000. Unfortunately, only 1 SWE measurement is made at the intercomparison site, but generally the spatial variability is low with snow depth exhibiting a coefficient of variation (COV) under $6 \%$ (with a maximum snow depth of just over $80 \mathrm{~cm}$ ). Therefore, the impact of spatial variability in SWE, even with a $25 \mathrm{~m}$ separation, is likely quite small for most of the season. However, both webcam photos and snow depth measurements provide evidence that snowmelt rates during ablation vary across the site, largely dependent on exposure. Manual snow depth measurements suggest that spatial differences in the area around the SWE measurements are small and are perhaps as high as $4 \mathrm{~cm}$ in mid-April of 2014 and less in midApril of 2015. These differences obviously account for very little of the late season SWE deviation shown in Fig. 5 (top). This also suggests that the CS725 move prior to the 2014/15 season had a low impact on sensor bias from one season to the next.

Caribou Creek, with maximum snow depths of 56 and $41 \mathrm{~cm}$ for the two consecutive seasons, exhibits a much higher spatial variability. Here, COV is about $15 \%(19 \%)$ at peak snow depth but increases to $30 \%(90 \%)$ during ablation for 2013/14 (2014/15). With a full five-point snow course performed here, mean SWE maximum is approximately $125 \mathrm{~mm}$ w.e. in $2013 / 14$ and $75 \mathrm{~mm}$ w.e. in $2014 / 15$ with COV very similar to those shown for snow depth. The manual measurement used in the intercomparison is made just inside the measurement area of the sensor, approximately $5 \mathrm{~m}$ from the centre. Although relatively close, the higher spatial variability could result in a spatial bias, especially during ablation. For example, in 2013/14, we estimate SWE to increase across the sensor measurement area by approximately $10 \mathrm{~mm}$ w.e. in late April due to differential melting as a result of exposure. With the manual measurement closer to the lower SWE estimate in the sensor measurement area, up to $25 \%$ of the difference in SWE between the sensor and the manual measurement (as shown in Fig. 5, middle left) could be explained.

The spatial variability is not assessed for Fortress Mountain or Weissfluhjoch.

\subsubsection{Experiment design}

Some aspects of the design of the SWE intercomparison are less than ideal and often were a result of compromise amongst the overall SPICE objectives, site host resources and nationally accepted practices. These compromises potentially contribute to some ambiguity of the study results and this commentary could form the basis for recommendations on the design of future SWE sensor intercomparisons.

Ideally, the manual reference at each site should have been identical using the same sampling equipment at a prescribed offset distance from each SWE sensor. Rather, each site host used their nationally accepted method of sampling SWE (as described in Sect. 2.3). Distances between the man- 
ual SWE measurement and the sensor varied from 5 to $25 \mathrm{~m}$, depending on site, but perhaps more significantly, the variation within the sensor measurement area (especially for the CS725) was not properly assessed. This could certainly have been a factor at Caribou Creek but the intense sampling within the measurement area of the sensor would have caused too much disturbance and impacted sensor measurements. Also, increased frequency (i.e. weekly) of manual measurements is desirable especially after significant changes in the snowpack, albeit at the risk of disturbance. In the future, manual observers should pay special attention to the existence of basal ice layers which may have an impact on the overall accuracy of the manual SWE estimate.

Another ideal situation would have been the co-location of both SWE sensor types at each site. This, in combination with soil moisture and temperature sensors within the measurement area of the CS725 sensors, would have provided additional information for the assessment of sensor bias. Another good addition would be the automated and high frequency measurement of snow depth within the sensor measurement areas to provide an indicator of snow density and melt rates and perhaps an indicator of snow bridging on the weighing SWE sensors.

\subsubsection{Manual SWE measurements}

As noted above, the manual SWE measurements differed by site, the exception being Caribou Creek and Fortress Mountain that both used the ESC-30 snow tube and bagged and weighed the sample. We will not comment further on possible bias associated with different samplers (Farnes et al., 1983; Goodison et al., 1987), as these are generally small as compared to the differences in the measurements shown in these results. We do, however, want to address possible errors associated with the manual measurement of a complex snowpack (i.e. a snowpack with ice layers or during melt), especially with a snow tube.

During the intercomparison, both Caribou Creek and Sodankylä experienced several freeze and thaw cycles over the course of the winter (as seen in Fig. 5 top and middle) but one was especially pronounced at Caribou Creek during mid- to late January 2015 (Fig. 5, middle right). The result of freezethaw is usually a "crusty" snowpack with several ice layers. In general, these characteristics make a snowpack difficult to sample with a snow tube as the tube cutters need to cut through multiple ice layers without snow escaping from the bottom of the tube (Powell, 1987; Sturm et al., 2010). It is anticipated that even an expert user will have difficulties obtaining an accurate sample in these conditions, exacerbated even more by the shallow pack found at Caribou Creek in 2014/15. It is difficult even at the time of the sample to estimate measurement error, but it could easily result in a 5-10 $\%$ underestimate of SWE. Sturm et al. (2010) reported an average underestimate from a snow tube of $7.1 \%$ as compared to layer-integrated snow pit measurements. Although this may explain some of the bias in the CS725 measurements, especially at Caribou Creek, it is countered by the relatively good agreement between the manual and SSG1000 measurements for Sodankylä. However, midwinter melting could also result in basal ice as the meltwater percolates through the snow and refreezes at the surface (providing that the surface is below $0{ }^{\circ} \mathrm{C}$ ) or in the top layer of the sandy substrate. Not only would this ice layer be difficult to measure with a snow tube (which is difficult to cut through and often results in an underestimate), the meltwater may drain off of the SSG1000 measurement surface and be underestimated by that measurement as well. This may partially explain the often (but sometimes inconsistent) increase in sensor bias shown by manual SWE measurements following midwinter freeze-thaw cycles in Fig. 5 (top and middle). Unfortunately, the observer's notes did not indicate when a basal ice layer was observed so much of this is speculation.

During ablation, measures were taken to sample the snowpack before it ripened but this could not always be accomplished due to travel time to the site (especially for Caribou Creek). Because the sample was bagged and weighed rather than weighed in the tube, a wet sample would experience some errors because of the bagging process (liquid water or sticky snow left in the tube) and result in an underestimate of SWE (perhaps $5 \%$ as a rough estimate).

\section{Summary and conclusions}

Two automated SWE sensors were tested at three WMOSPICE sites (Sodankylä, Weissfluhjoch and Caribou Creek) and at one additional Canadian site (Fortress Mountain) during the WMO-SPICE intercomparison (northern hemispheric) winters of 2013/14 and 2014/15. Instrument measurements were compared to periodic manual measurements of SWE at the sites and cross referenced with ancillary measurements of air temperature and soil moisture and soil temperature (at Caribou Creek) to try to determine causality for some of the bias seen in the intercomparison. The objective was not necessarily to determine which instrument makes the most accurate measurement, but to inform users of potential measurement issues that may influence their data interpretation.

Intercomparison results for the CS725 show that it overestimates SWE on average by 30 and $35 \%$ at Sodankylä and Caribou Creek, respectively, with combined season correlations $\left(r^{2}\right)$ of 0.92 at Sodankylä and 0.90 at Caribou Creek. Interseasonal variability in both the MRB and the correlations were higher at Caribou Creek, the differences attributed to smaller sample sizes, higher spatial variability of SWE and ice layers in the snowpack. Offsets were generally higher at Caribou Creek, which could be indicative of an inaccurate soil moisture calibration of the instrument, a change in soil moisture relative to the calibration prior to or after the soil freezing or sampling errors in the manual SWE mea- 
surement due to a more complex snowpack. Correlations at Fortress Mountain are also quite high over the single intercomparison season $\left(r^{2}=0.92\right)$ with a mean negative bias of approximately $5 \%$, which is more comparable to the results of Wright et al. (2011) in similar conditions. At the two sandy SPICE sites, the agreement between the CS725 and the manual SWE measurements are generally better prior to the start of seasonal ablation. We believe this occurs largely because of early spring melt percolating through the snowpack and either forming a basal ice layer or infiltrating into the sandy substrate. Either way, this water is difficult or impossible to measure with a snow tube. However, because this water continues to attenuate the gamma radiation signal detected by the CS725, the sensor still interprets this water as SWE and therefore appears to overestimate as compared to the manual measurements. Seasonal ablation has no significant impact on the agreement at Fortress Mountain due to saturated frozen soils that restrict infiltration and a mild slope that promotes runoff of meltwater from the site.

The SSG1000 at both Sodankylä and Weissfluhjoch compared quite well to the manual SWE measurements showing mean biases of -11 and $8 \%$ at the respective sites. It did, however, experience some technical issues at Sodankylä early in the 2014/15 snowmelt period which limited the intercomparison for that season. The correlations were quite high with the combined season $r^{2}$ ranging from 0.88 at Sodankylä to 0.96 at Weissfluhjoch. Many of the outliers in the SSG1000 intercomparisons are most likely due to bridging of the snowpack on the weighing plate but we also have to consider errors related to the manual measurements and other processes going on at the snow-soil-sensor interface (as outlined in Johnson, 2004). At Weissfluhjoch, these outlier events occurred prior to maximum seasonal SWE while at Sodankylä they occurred during ablation. Removing the ablation period in the 2013/14 Sodankylä data resulted in a substantial increase in $r^{2}$ from 0.84 to 0.97 .

The SSG1000 correlated very well with the CS725 at Sodankylä during the accumulation period. Although the overestimation of SWE by the CS725 is quite apparent when compared against the SSG1000, the accumulation period $r^{2}$ was 0.98 and 0.99 for the two respective seasons. Intercomparison of the two sensors clearly shows how the overestimation of SWE by the CS725 increases at the onset of ablation in March/April of the 2013/14 season. Independent of the manual measurements, this indicates that the deviation of the CS725 from manual SWE during ablation is most likely instrument related and a result of the CS725 misinterpreting the meltwater infiltrated into the sandy soils as SWE.

When comparing SWE instruments to a manual reference, there are several considerations that must be made that ultimately impact the interpretation of the results. We know that the manual measurements of SWE are not free of error. Experience proves that making a snow tube bulk density sample in a snowpack containing ice layers or during melt is difficult and inherently prone to errors. We also have to consider the spatial variability of the snow that we are sampling as the CS725 (and the SSG1000 to a lesser degree) have a much larger measurement area than the manual point sample. Taking this and the technical capabilities of the instruments into consideration, both sensors have high correlations (generally higher than 0.90, Caribou Creek being the exception) with the manual reference measurements. We have identified that the SSG1000 has had some technical issues during snowmelt but are satisfied that these issues can be overcome with some installation modifications. The SSG1000 may also underestimate SWE on occasion due to bridging so users need to be aware of this potential error. We have identified the potential for the CS725 measurements to be misinterpreted, especially when deployed over sandy soils and during melting conditions. Although more verification work is required on the impact of soil moisture change on the CS725 bias, aggregating subsurface moisture in the SWE estimate could potentially be useful from a hydrological perspective as it ultimately impacts the amount of water available for runoff. Nevertheless, it is recommended to co-locate the CS725 with ancillary measurements of soil moisture, soil temperature and snow depth to guide the user in interpreting the data.

\section{Data availability}

Much of the data used in this analysis were collected during the SPICE project on behalf of the WMO Commission for Instruments and Methods of Observations (CIMO). At the time of publication, the SPICE final report remains in progress and the project data protocol limits data availability until the final report is released, at which time the data can be obtained by contacting the corresponding author.

Acknowledgement. We wish to thank the WSL Institute for Snow and Avalanche Research SLF for kindly providing the SSG1000 and manual SWE measurements from Weissfluhjoch as well as the countless other contributors to SPICE who helped to make the project a success. We would like to express our appreciation for the effort that the reviewers and the special issue editor provided to help us improve this paper with a special thanks to Charles Fierz (WSL-SLF, Davos), who provided a very thorough review with substantial and helpful feedback.

Edited by: S. Morin

Reviewed by: C. Fierz and two anonymous referees

Disclaimer. Many of the results presented in this work were obtained as part of the Solid Precipitation Intercomparison Experiment (SPICE) conducted on behalf of the World Meteorological Organization (WMO) Commission for Instruments and Methods of Observation (CIMO). The analysis and views described herein are those of the authors at this time and do not necessarily represent the official outcome of WMO-SPICE. Mention of commercial companies or products is solely for the purposes of information and assessment 
within the scope of the present work and does not constitute a commercial endorsement of any instrument or instrument manufacturer by the authors or the WMO.

\section{References}

Anderson, D. W.: BOREAS TE-01 SSA Soil Lab Data, from Oak Ridge National Laboratory Distributed Active Archive Center, Oak Ridge, Tennessee, USA, doi:10.3334/ORNLDAAC/530, available at: http://www.daac.ornl.gov, last access: September 2016, 2000.

Barnett, T. P., Adam, J. C., and Lettenmaier, D. P.: Potential impacts of a warming climate on water availability in snow dominated regions, Nature, 438, 303-309, 2005.

Bartlett, P. A., MacKay, M. D., and Verseghy, D. L.: Modified snow algorithms in the Canadian Land Surface Scheme: Model runs and sensitivity analysis at three boreal forest stands, Atmos. Ocean, 44, 207-222, 2006.

Barry, R. G.: Observing systems and data sets related to the cryosphere in Canada: A contribution to planning for the Global Climate Observing System, Atmos. Ocean, 33, 771-807, 1995.

Beaumont, R. T.: Mt. Hood pressure pillow snow gage, J. Appl. Meteorol., 4, 626-631, 1965.

Beaumont, R. T.: Snow accumulation, in: Proceedings of the 34th Annual Western Snow Conference, April 1966, Seattle, Washington, 3-6, 1966a.

Beaumont, R. T.: Evaluation of the Mt. Hood pressure pillow snow gage and application to forecasting avalanche hazard, IASH Publications no. 69, 341-349, 1966b.

Brown, R. D., Walker, A. E., and Goodison, B.: Seasonal snow cover monitoring in Canada: an assessment of Canadian contributions for global climate monitoring, in: 57th Eastern Snow Conference, Syracuse, New York, USA, 17-19 May 2000, 131141, 2000.

Choquette Y., Lavigne, P., Nadeau, M., Ducharme, P., Martin, J. P., Houdayer, A., and Rogoza, J.: GMON, a new sensor for snow water equivalent via gamma monitoring, Proceedings Whistler 2008 International Snow Science Workshop, 21-27 September 2008, Whistler, B.C., 2008.

Derksen, C., Walker, A., and Goodison, B.: Evaluation of passive microwave snow water equivalent retrievals across the boreal forest/tundra transition of western Canada, Remote Sens. Environ., 96, 315-327, 2005.

Engeset, R., Sorteberg, H., and Udnaes, H.: Snow pillows: Use and verification, in: Snow Engineering: Recent Advances and Developments. Proceedings of the Fourth International Conference on Snow Engineering, Trondheim, Norway, 19-21 June 2000, edited by: Hjorth-Hansen, E., HOLAND, I., Loset, S., and Norem, H., AA Balkema, Rotterdam, Netherlands, 45-51, 2000.

Farnes, P. F., Goodison, B. E., Peterson, N. R., and Richards, R. P.: Metrication of manual snow sampling equipment, Final report Western Snow Conference, 19-21 April 1983, Spokane, Washington, 106 pp., 1983.

Goodison, B. E. and Walker, A. E.: Canadian development and use of snow cover information from passive microwave satellite data, in: Passive Microwave Remote Sensing of Land-Atmosphere Interactions, edited by: Choudhury, B. J., Kerr, Y. H., Njoku, E. G., and Pampaloni, P., Utrecht, The Netherlands, 245-262, 1995.
Goodison, B. E., Glynn, J. E., Harvey, K. D., and Slater, J. E.: Snow surveying in Canada: A perspective, Can. Water Resour. J., 12, 27-42, doi:10.4296/cwrj1202027, 1987.

Gray, D. M., Granger, R. J., and Dyck, G. E.: Overwinter soil moisture changes, Transactions of the ASAE, 28, 442-447, 1985.

Gray, D. M., Toth, B., Zhao, L., Pomeroy, J. W., and Granger, R. J.: Estimating areal snowmelt infiltration into frozen soils, Hydrol. Process., 15, 3095-3111, 2001.

Harding, R. J.: Exchanges of energy and mass associated with melting snowpack, in: Modelling Snowmelt-Induced Processes, Proc. of the Budapest Symposium, IAHS Press, Institute of Hydrology, Wallingford, UK, IAHS Publications No. 155, 3-15, 1986.

Johnson, J. B.: A theory of pressure sensor performance in snow, Hydrol. Process., 18, 53-64, doi:10.1002/hyp.1310, 2004.

Johnson, J. B., Gelvin, A., and Schaefer, G.: An engineering design study of electronic snow water equivalent sensor performance, Proc. 75 ${ }^{\text {th }}$ Western Snow Conf., 23-30, 2007.

Johnson, J. B., Gelvin, A. B., Duvoy, P., Schaefer, G. L., Poole, G., and Horton, G. D.: Performance characteristics of a new electronic snow water equivalent sensor in different climates, Hydrol. Process., 29, 1418-1433, doi:10.1002/hyp.10211, 2015.

Jonas, T., Marty, C., and Magnusson, J.: Estimating the snow water equivalent from snow depth measurements in the Swiss Alps, J. Hydrol., 378, 161-167, doi:10.1016/j.jhydrol.2009.09.021, 2009.

Kinar, N. J. and Pomeroy, J. W.: Determining snow water equivalent by acoustic sounding, Hydrol. Process., 21, 2623-2640, doi:10.1002/hyp.6793, 2007.

Kinar, N. J. and Pomeroy, J. W.: SAS2: the system for acoustic sensing of snow, Hydrol. Process., 29, 4032-4050, doi:10.1002/hyp.10535, 2015a.

Kinar, N. J. and Pomeroy, J. W.: Measurements of the physical properties of the snowpack, Rev. Geophys., 53, 481-544, doi:10.1002/2015RG000481, 2015b.

Kodama, M., Nakai, K., Kawasaki, S., and Wada, M.: An application of cosmic-ray neutron measurements to the determination of the snow-water equivalent, J. Hydrol., 41, 85-92, 1979.

Kuusisto, E.: Snow accumulation and snowmelt in Finland, National Board of Waters, Helsinki, Finland, Publications of the Water Research Institute No. 55, 149 pp., 1984.

Lambe, W. T. and Whitman, R. V.: Description of an Assemblage of Particles, Soil Mechanics, 1st Edn., John Wiley \& Sons, Inc., Chapter 3, 553 pp., 1969.

Laukkanen, A.: Short term inflow forecasting in the Nordic power market, Master thesis, Physics and Mathematics, Helsinki University of Technology, Helsinki, 60 pp., 2004.

Lilbaek, G. and Pomeroy, J. W.: Ion enrichment of snowmelt runoff water caused by basal ice formation, Hydrol. Process., 22, 27582766, 2008.

Martin, J. P., Houdayer, A., Lebel, C., Choquette, Y., Lavigne, P., and Ducharme, P.: An unattended gamma monitor for the determination of snow water equivalent (SWE) using the natural ground gamma radiation, in: 2008 IEEE Nuclear Science Symposium Conference Record, Dresden, Germany, 19-25 October 2008, 983-988, doi:10.1109/NSSMIC.2008.4774560, 2008.

Nitu, R., Rasmussen, R., Baker, B., Lanzinger, E., Joe, P., Yang, D., Smith, C., Roulet, Y., Goodison, B., Liang, H., Sabatini, F., Kochendorfer, J., Wolff, M., Hendrikx, J., Vuerich, E., Lanza, L., Aulamo, O., and Vuglinsky, V.: WMO intercomparison 
of instruments and methods for the measurement of solid precipitation and snow on the ground: organization of the experiment, WMO Technical Conference on meteorological and environmental instruments and methods of observations, Brussels, Belgium, 16-18 October 2012, 10 pp., available at: http://www.wmo.int/pages/prog/www/IMOP/publications/ IOM-109_TECO-2012/Session1/O1_01_Nitu_SPICE.pdf last access: 5 January 2017, 2012.

Pomeroy, J. W. and Gray, D. M.: Snowcover accumulation, relocation, and management, National Water Research Institute, Saskatoon, Canada, National Hydrology Research Institute Science Report No. 7, 144 pp., 1995.

Powell, D.: Observations on consistency and reliability of field data in snow survey measurements, presented at: 55th Annual Meeting Western Snow Conference, Vancouver, B.C., 14-16 April 1987, 69-77, 1987.

Rasmussen, R., Baker, B., Kochendorfer, J., Meyers, T., Landolt, S., Fischer A. P., Black, J., Thériault, J. M., Kucera, P., Gochis, D., Smith, C., Nitu, R., Hall, M., Ikeda, K., and Gutmann, E.: How well are we measuring snow: The NOAA/FAA/NCAR winter precipitation test bed, B. Am. Meteorol. Soc., 93, 811-829, 2012.

Serreze, M. C., Clark, M. P., Armstrong, R. L., McGinnis, D. A., and Pulwarty, R. S.: Characteristics of the western United States snowpack from snowpack telemetry (SNOTEL) data, Water Resour. Res., 35, 2145-2160, 1999.
Stranden, H. B. and Grønsten, H. A.: Filefjell Snow Research Station, Evaluation of recorded data for snow seasons 2009/2010 and 2010/2011 (English Summary), Norwegian water resourcesand energy directorate, Oslo, Report No. 23/2011, 27 pp., 2011.

Sturm, M., Taras, B., Liston, G. E., Derksen, C., Jonas, T., and Lea, J.: Estimating Snow Water Equivalent Using Snow Depth Data and Climate Classes, J. Hydrometeorol., 11, 1380-1394, doi:10.1175/2010JHM1202.1, 2010.

Takala, M., Luojus, K., Pulliainen, J., Derksen, C., Lemmetyinen, J., Kärnä, J.-P., and Koskinen, J.: Estimating northern hemisphere snow water equivalent for climate research through assimilation of space-borne radiometer data and ground-based measurements, Remote Sens. Environ., 115, 3517-3529, 2011.

Tollan, A.: Experiences with snow pillows in Norway, International Association of Scientific Hydrology, Bulletin, 15, 113120, 1970.

WMO (World Meteorological Organization): Guide to hydrological practices, Volume 1: Hydrology - From measurements to hydrological information, 6th Edn., WMO, Geneva, WMO-No. 168, 296 pp., 2008.

Woo, M., Heron, R., and Marsh, P.: Basal ice in high Arctic snowpacks, Arctic Alpine Res., 14, 251-260, 1982.

Wright, M., Kavanaugh, K., and Labine, C.: Performance analysis of the GMON3 snow water equivalency sensor, Proceedings of the 79th Annual Western Snow Conference, Stateline, NV, April 2011. 